УДК 347.211:061.1€С

\author{
Бояр Андрій, \\ доктор економічних наук, професор, \\ Волинський національний університет імені Лесі Українки, \\ кафедра міжнародних економічних відносин та управління просктами, \\ м. Луцьк, ORCID ID 0000-0002-9379-8140, \\ e-mail: Andrij.Boyar@vnu.edu.ua \\ Щербата Надія, \\ кандидат економічних наук, старший викладач, \\ Волинський національний університет імені Лесі Українки, \\ кафедра міжнародних економічних відносин та управління проєктами, \\ м. Луцьк, ORCID ID 0000-0002-4688-9138, \\ e-mail: nadijascience@outlook.com
}

https://doi.org/10.29038/2786-4618-2021-04-16-24

\title{
МЕТАМОРФОЗА СИСТЕМИ ОХОРОНИ ПРАВ ІНТЕЛЕКТУАЛЬНОЇ ВЛАСНОСТІ У СВРОПЕЙСЬКОМУ СОЮЗІ
}

У статті проаналізовано функціональну структуру системи охорони інтелектуальної власності у Європейському Союзі (СС). Виділено два вектори сучасно європейської політики у сфері охорони прав інтелектуальної власності: внутрішній та зовнішній. Окреслено їх цільове спрямування та функціональні особливості. Виявлені ключові суб'єкти реалізації єдиної політики ЄС у сфері інтелектуальної власності: інституції ЄС (Свропейський парламент, Рада ЄС та Європейська комісія), Європейська патентна організація, Управління ЄС з питань інтелектуальної власності. Встановлено їх функції та механізми взаємодії, зокрема через Мережу інтелектуальної власності СС. Розкрито тенденції розвитку системи, особливості охорони різних категорій об’єктів права інтелектуальної власності в ЄС в умовах сучасних технологічних досягнень, цифровізації та пандемії COVID-19.

Ключові слова: інтелектуальна власність, Європейський Союз, єдиний ринок, торговельна марка, промисловий зразок, винахід, диджиталізація, пандемія.

Бояр Андрий, доктор экономических наук, профессор, Волынский национальный университет имени Леси Украинки, кафедра международных экономических отношений и управления проектами, г. Луцк

Щербата Надия, кандидат экономических наук, старший преподаватель, Волынский национальный университет имени Леси Украинки, кафедра международных экономических отношений и управления проектами, г. Луцк

\section{МЕТАМОРФОЗА СИСТЕМЫ ОХРАНЫ ПРАВ ИНТЕЛЛЕКТУАЛЬНОЙ СОБСТВЕННОСТИ В ЕВРОПЕЙСКОМ СОЮЗЕ}

В статье проанализирована институционально-правовая структура системы охраны интеллектуальной собственности в Европейском Союзе (ЕС). Выделены два вектора современной европейской политики в сфере охраны прав интеллектуальной собственности: внутренний и внешний. Определены их целевое направление и функциональные особенности. Выявлены ключевые субъекты реализации единой политики ЕС в сфере интеллектуальной собственности: институции ЕС (Европейский парламент, Совет ЕС и Европейская комиссия), Европейская патентная организация, Управление ЕС по вопросам интеллектуальной собственности. Установлено их функции и механизмы взаимодействия, в частности через Сеть интеллектуальной собственности ЕС. Раскрыты тенденции развития системы, особенности охраны различных категорий объектов 
права интеллектуальной собственности в ЕС в условиях современных технологических достижений, цифровизации и пандемии COVID-19.

Ключевые слова: интеллектуальная собственность, Европейский Союз, единый рынок, торговая марка, промышленный образец, изобретение, диджитализация, пандемия.

\section{Andrii Boiar, Doctor of Economics, Professor, Lesya Ukrainka Volyn National University, Department of International Economic Relations and Project Management,} Lutsk, Shcherbata Nadiia,
Candidate of Economic Sciences, Senior Lecturer,
Lesya Ukrainka Volyn National University,
Department of International Economic Relations and Project Management, Lutsk,

\section{METAMORPHOSIS OF INTELLECTUAL PROPERTY RIGHTS PROTECTION IN THE EUROPEAN UNION}

The European Union (EU) common policy in the field of intellectual property (IP) attracts more and more attention of scientists and practitioners for a number of reasons. It is dynamically developing sector and important factor of economic development in the context of digital transformation. Therefore, this article analyses the institutional and legal structure of the EU IP protection system.

Two vectors of modern European policy in the field of IP rights protection are highlighted: internal and external. Their target direction and functional features are outlined. Key subjects of implementation of the EU's unified policy in the field of IP have been identified: the EU institutions (European Parliament, Council of the EU and European Commission), European Patent Organization, the EU Intellectual Property Office. Their functions and mechanisms of interaction have been established, in particular through the EU Intellectual Property Network. The trends in the development of the system, peculiarities of protection of various categories of IP objects in the EU in the context of modern technological achievements, digitalization and the COVID-19 pandemic have been revealed.

The EU IP objects can be classified into three groups: industrial property (inventions, utility models, industrial designs, trademarks, indication of the origin; objects of copyright and related rights (literary works, works of art, computer programs, databases, performances, phonograms and videograms, programs of broadcasting organizations) and other objects of IP rights (plant varieties, animals, topography of integrated microcircuits, etc.

Today, the EU IP policy is aimed at improving the ways of protection IP rights, strengthening their use (primarily in business), promoting licensing and common use, ensuring better counteraction to IP rights violations and promoting fair play at the global level. It is one of the most effective in the world, harmoniously combined with the processes of development of the single market, increasing the dynamism and competitiveness of the EU economy, the formation of an information society with a high degree of innovative and investment attractiveness.

Keywords: intellectual property, European Union, single market, trademark, industrial design, invention, digitalization, pandemic.

Постановка проблеми. Прискорення та просування диджиталізації, що регулюється системою інтелектуальної власності, - це унікальна можливість стимулювати економіку та розвивати інноваційне середовище. Глобальна пандемія COVID-19 та економічна криза поставили цифрові технології в центр глобальної уваги. Інновації та інтелектуальна власність відіграють основну роль у боротьбі з пандемією та у відновленні економіки світу. Криза COVID-19 проілюструвала залежність усіх країн світу від інновацій та технологій, нагадала про важливість оперативного правового регулювання інтелектуальної власності. Цифрова трансформація, яка стає ключовим рушієм економічного відновлення, вимагає, щоб інтелектуальна власність мала такі ж темпи змін та адаптації. Звідси виникає потреба дослідження метаморфози інституційно-правового регулювання інтелектуальної власності СС, як одного з лідерів реформ у цій сфері, на якого наша держава 
повинна орієнтуватись відповідно до іiї євроінтеграційного курсу та умов реалізації Угоди про асоціацію між Україною та ЄС.

Єдина політика Європейського Союзу у сфері інтелектуальної власності привертає все більшу увагу науковців, практиків у різних аспектах. По-перше, як новий інститут права, який динамічно розвивається, об'єднує успішні ініціативи з введення регіонального захисту прав інтелектуальної власності. По-друге, як важливий чинник економічного розвитку в умовах цифрової трансформації, як фактор створення середовища, сприятливого для виробництва нових та вдосконалених інновацій. По-третє, як сфера співробітництва з Україною в умовах європейської інтеграції.

Аналіз останніх досліджень та публікацій. Питання охорони інтелектуальної власності у країнах Європейського Союзу досліджувалися Г.О. Андрощуком, В.С. Дроб'язко, В.О. Жаровим, І.Ю. Кожарською, Ю.М. Капіцею, М.В. Паладієм, Г.В. Цірат та іншими фахівцями. У наукових публікаціях цих вчених вивчається досвід ЄС у сфері охорони інтелектуальної власності, здійснюється порівняльний аналіз права інтелектуальної власності європейських країн, аналізується правова система охорони інтелектуальної власності України 3 позицій відповідності нормам ЄС тощо.

Виділення невирішених раніше частин загальної проблеми. Не дивлячись на існуючі дослідження досвіду ЄС у сфері охорони інтелектуальної власності, актуальними стали дослідження модернізації політики ЄС у цій сфері відповідно до викликів сьогодення. Тому, метою даної статті $є$ проаналізувати розвиток інституційно-правового регулювання інтелектуальної власності в ЄС 3 позицій нових викликів, зумовлених новітніми технологічними розробками, процесами диджиталізації, світовою пандемією тощо.

Виклад основного матеріалу. СС приділяє важливу роль гармонізації та вдосконаленню законів, що стосуються прав інтелектуальної власності. Надійна система охорони інтелектуальної власності (IB) - найкращий спосіб використати інтелектуальні здібності та дати можливість розвиватись інноваційним підприємствам. Без захисту ідей приватні та юридичні особи не змогли б скористатися всіма перевагами своїх винаходів чи творінь і менше б зосереджувались на дослідженнях та розробках.

Інтелектуальна власність має вирішальне значення для економіки СС. Галузі, які базуються на використанні об'єктів інтелектуальної власності формують майже 45 \% ВВП ЄС - 6,6 трлн євро, забезпечують $30 \%$ загальної зайнятості в СС [11].

Нематеріальні активи, такі як винаходи, художні та культурні твори, бренди, програмне забезпечення, ноу-хау, бізнес-процеси та дані, є наріжними каменями сучасної економіки. За останні два десятиліття, обсяг щорічних інвестицій у «продукти інтелектуальної власності" збільшився в СС на $87 \%$ [2].

Це означає, що захист прав інтелектуальної власності $€$ надзвичайно важливим для успіху єдиного ринку ЄС, для просування інновацій та креативності, а також для зростання зайнятості та підвищення конкурентоспроможності економіки СС.

Сучасна політика Євросоюзу в сфері інтелектуальної власності носить два чітких векторних спрямування. По-перше, це внутрішній вектор, який передбачає створення єдиної гармонізованої системи охорони прав інтелектуальної власності в межах самого ЄС. Досягнення цієї мети розглядається як один 3 важливих кроків на шляху до завершення формування єдиного ринку, підвищення динамізму, гнучкості економіки $\mathrm{CC}$, оптимізації конкурентного середовища. Створення єдиної європейської системи охорони об'єктів права інтелектуальної власності дає змогу підвищити конкурентоспроможність і привабливість європейської економіки у світі, забезпечує безпеку і захист творчої діяльності громадян на теренах усього Євросоюзу, дає поштовх розвитку інноваційної діяльності та створює привабливий клімат для інвестування в Європу.

По-друге, це зовнішній вектор, який полягає у прагненні ЄС стимулювати створення ефективних систем охорони інтелектуальної власності в третіх країнах, сприяти розвитку міжнародного співробітництва у цій сфері. У рамках цього вектору знаходять відображення такі інтереси Євросоюзу як намагання забезпечити європейським компаніям охорону їх інновацій за кордоном, ефективніше боротись 3 імпортом до ЄС неліцензованої продукції, розширити ринки збуту, стимулювати міжнародну торгівлю та транскордонні інвестиційні проекти [1]. 
Повноваження та відповідальність за формування єдиної політики $\epsilon C$, у тому числі у сфері інтелектуальної власності, розділяють між собою основні законодавчі, виконавчі та судові органи Союзу: Європейський парламент, Рада $\mathrm{CC}$, Свропейська комісія та Суд $\mathrm{CC}$, які намагаються гармонізувати права інтелектуальної власності шляхом створення єдиної європейської системи паралельно $з$ національними системами, як це відбувається у випадку торговельної марки та промислового зразка $Є С$ та європейського унітарного патенту.

Функції Комісії полягають у розробці проектів нормативно-правових актів (вторинне законодавство) щодо охорони прав інтелектуальної власності та впровадженні їх в дію 3 метою створення сприятливих умов для розвитку єдиного ринку ЄС. Європарламент та Рада ухвалюють підготовлені Комісією проекти актів вторинного законодавства рішення у формі директив, регламентів, рішень; ратифікують міжнародні договори. Суд ЄС вирішує спірні питання, що можуть виникати в процесі прийняття рішень, та виступає вищою інстанцією у процесі врегулювання правовідносин між суб'єктами права.

Крім того, існують такі спеціалізовані установи як Європейська патентна організація (European Patent Organization) та Управління Свропейського Союзу з питань інтелектуальної власності (European Union Intellectual Property Office).

Європейська патентна організаиія (ЄПО) (штаб-квартира у Мюнхені, Німеччина) є незалежною від СС та інших регіональних і міжнародних структур, створена 7 жовтня 1977 р. на підставі Європейської патентної конвенції (ЄПК). Вона забезпечує заявнику видачу єдиного патенту на винахід (європейський патент), за яким його права охороняються в одній, кількох або усіх країнахучасницях відповідно до вказаного у заявці переліку. Причому видача охоронного документу відбувається в рамках єдиної процедури і на підставі однієї поданої заявки. Такий патент має такий самий статус і підлягає такому ж регулюванню, що й національний патент країни-учасниці ЄПК. Станом на 01 серпня 2021 р. ЄПО об'єднує 38 країн-учасниць. ЄПО складається 3 виконавчого органу - Свропейського патентного відомства і адміністративного органу - Адміністративної Ради [6].

ЄПО повністю фінансується за рахунок зборів, які сплачують держави-члени. У 2021 р. бюджет ЄПО становив 2,4 млрд євро [5].

Попит на європейські патенти залишається стабільним. У 2020 р. ЄПО отримало 180250 заявок, що лише на $0,7 \%$ менше, ніж у 2019 р., не зважаючи на пандемію.

У 2019 р. прийнято Стратегічний план ЄПО на 2023 рік, який містить чітку дорожню карту для досягнення нового бачення Організації, а його реалізація забезпечить, щоб ЄПО продовжувала надавати високоякісні патентні послуги, які заохочують інновації та сприяють зростанню [12].

Управління Свропейського Союзу з питань інтелектуальної власності відповідає за реєстрацію торговельних марок й промислових зразків $Є С$ та пропонує підприємствам і громадянам виключні права на їх охорону по всій території Союзу за єдиною заявкою.

Раніше Управління СС 3 питань інтелектуальної власності було відоме як Управління 3 гармонізації внутрішнього ринку (Office of the Harmonization in the Internal Market), яке було створене відповідно до Регламенту Ради СС щодо торговельної марки Співтовариства від 23 грудня 1993 р. Пройшовши реформи, з березня 2016 року Управління відоме під своєю нинішньою назвою. Офіс Управління розташований у м. Аліканте в Іспанії. При Управлінні створено два колегіальних органи, до яких входять представники країн-членів $\mathrm{CC}$, Свропейської комісії та Європейського парламенту: Правління (до 2016 р. Адміністративна Рада) і Бюджетний комітет. Управління не $є$ структурним підрозділом виконавчого органу $\mathrm{CC}$, але діє в рамках законодавчих актів, прийнятих Радою і Парламентом ЄС, та відповідно до нормативно-правових актів, прийнятих Комісією в межах iї компетенцій. Тому діяльність Управління здійснюється під адміністративно-правовим впливом інституцій ЄС.

Щорічно в Управлінні реєструються 135000 торговельних марок ЄС та близько 100000 промислових зразків, що забезпечують захист інтелектуальної власності компаніям та приватним особам на ринку з більш ніж 500 мільйонами споживачів [13].

32012 року в Управлінні розміщена Європейська обсерваторія 3 питань порушення прав інтелектуальної власності, яка об'єднує державні та приватні зацікавлені сторони у боротьбі 3 
піратством та підробкою. Для Управління це означало стати активним учасником наступного етапу життєвого циклу інтелектуальної власності - сприяти захисту прав на результатів творчої та інноваційної діяльності після їх реєстрації торговельної марки [4].

3 моменту заснування основним завданням Управління була реєстрація торговельних марок та промислових зразків, права на які дійсні на території ЄС. Однак сьогодні діяльність Управління також поширюється на гармонізацію практики реєстрації та розробку спільних інструментів охорони. Це призвело до створення Мережі інтелектуальної власності $6 C$ (European Union Intellectual Property Network), яка об'єднує Управління, національні та регіональні офіси з питань інтелектуальної власності країн-членів $Є С$, міжнародних партнерів та клієнтів Управління для підвищення ефективності, інформативності та прозорості охорони прав інтелектуальної власності у ЄC [9]. Мета мережі - надати високоякісну експертизу для користувачів системи інтелектуальної власності, пропонуючи сучасні електронні послуги, полегшуючи доступ до інформації та гармонізуючи практику перевірки та реєстрації торговельних марок та промислових зразків.

Ще одна 3 цілей Управління - стати установою без паперів. Для цього відбувається реєстрація торговельних марок та промислових зразків в Інтернеті: на сьогоднішній день майже $99 \%$ усіх заявок на товарні знаки подаються в Інтернеті, а понад 75000 користувачів зареєструвалися як користувачі веб-сайту Управління.

Управління користується юридичною, адміністративною та фінансовою автономією. Усі його операції фінансуються за рахунок реєстраційних зборів, не покладаючи на Європейський Союз або його платників податків ніякого навантаження.

Об'єкти права інтелектуальної власності $Є С$ можна розділити на три групи: 1) об'єкти промислової власності (винаходи, корисні моделі, промислові зразки, торговельні марки, зазначення (вказівки) походження товару, фірмові найменування); 2) об'єкти авторського права і суміжних прав (літературні твори, твори мистецтва, комп'ютерні програми, бази даних, виконання творів, фонограми і відеограми, програми організацій мовлення) та 3) інші об'єкти права інтелектуальної власності (сорти рослин, породи тварин, топографії інтегральних мікросхем тощо). Акцентуємо увагу на особливостях охорони окремих з них.

Охорона промислової власності в Союзі посідає важливе місце у боротьбі з перешкодами для вільного руху товарів і послуг.

В ЄС законодавча база щодо торговельних марок базується на чотирирівневій системі реєстрації, яка співіснує з національними системами, гармонізованими за допомогою Директиви про торговельні марки [3]. Заявки на товарний знак можуть бути подані за такими процедурами:

- національний маршрут - заявки можна подавати безпосередньо до національного відомства 3 торговельних марок країни-члена $С \mathrm{C}$, наприклад, до німецького чи французького відомства 3 питань інтелектуальної власності. Загалом, національна торговельна марка охороняється лише в країні, в якій вона зареєстрована;

- регіональний маршрут - це спеціалізований регіональний варіант для заявників, які хочуть захисту в Бельгії, Нідерландах та Люксембурзі. Заявки можна подавати до Управління інтелектуальної власності Бенілюксу (ВОІР);

- загальноєвропейський маршрут - реєстрація позначення як торговельної марки Європейського Союзу (ССТМ) через Управління СС з питань інтелектуальної власності. ССТМ охоплює всі країни-члени $Є С$ і може бути зареєстрований, присвоєний або скасований лише щодо всього ЄС. Права на ЄСТМ чинні протягом 10 років 3 дати подання заявки та можуть бути продовжені необмежену кількість разів на наступні 10 років. Доступ до загальноєвропейської системи охорони ССТМ також можна отримати відповідно до процедури, передбаченої Мадридською угодою про міжнародну реєстрацію знаків;

- міжнародний маршрут - торговельні марки, що охороняються на підставі державної реєстрації у державі-учасниці Мадридської угоди про міжнародну реєстрацію знаків, можна подавати на реєстрацію в інших країнах-учасницях цієї угоди [10].

Патент може бути наданий будь-якому винаходу, що має технічний характер, за умови, що він $\epsilon$ новим, передбачає винахідницький рівень і може мати промислове використання. Патент надає власнику право перешкоджати іншим виробляти, використовувати або продавати винахід без 
дозволу. Патенти заохочують компанії робити необхідні інвестиції в інновації та стимулюють приватних осіб та компанії спрямовувати ресурси на дослідження та розробки.

У період з 2010 по 2019 рік кількість наданих європейських патентів зросла приблизно з 58000 до 137 000. Якість патентів, виданих у Європі, є однією з найвищих у світі. ЄС в подальшому має намір зберегти лідерство у сфері технологій [2].

У СС технічні винаходи можуть бути захищені або національними патентами, виданими компетентними національними органами, або європейськими патентами, що надаються централізовано ЄПО, заощаджуючи винахідникам витрати на паралельні заявки, забезпечуючи при цьому високу якість наданих патентів.

У 2012 році країни СС та Європейський парламент домовились про «патентний пакет»законодавчу ініціативу, що складається з двох нормативних актів та міжнародної угоди, яка закладає основу для створення єдиного патентного захисту в СС. Пакет складається 3 положення про створення європейського патенту 3 єдиним ефектом («унітарний патент»), положення, що встановлює мовний режим, що застосовується до унітарного патенту, угоди між країнами ЄС про створення єдиної та спеціалізованої патентної юрисдикції («Сдиний патентний суд»). Положення передбачають посилену співпрацю у створенні єдиного патентного захисту.

Унітарний патент - це юридична назва, яка забезпечить рівномірний захист у всіх країнахучасницях за принципом єдиного вікна, забезпечуючи величезні переваги у витратах та зменшуючи адміністративне навантаження. Цей пакет також створить Єдиний патентний суд, який запропонує єдину спеціалізовану патентну юрисдикцію ЄС.

Єдина патентна охорона дозволить винахідникам (приватним особам, компаніям чи установам) захистити свій винахід у всіх країнах-членах шляхом подання єдиної заявки на патент. Після видачі патенту не буде необхідності підтверджувати його в кожній країні-члені Союзу. Сдиний патентний захист зробить існуючу європейську систему простішою та дешевшою для винахідників. Очікується, що це стимулюватиме дослідження, розробки та інвестиції в інновації, сприяючи стимулюванню зростання в ЄС.

У листопаді 2015 року країни $Є С$ досягли важливої домовленості про фінансовий розподіл доходів від унітарних патентів [14]. Угода фіксує ключ розподілу для початкового періоду експлуатації: 50 \% податків зберігатиметься у ЄПО, а решта (за вирахуванням адміністративного збору) розподілятиметься між країнами-учасницями згідно з формулою, яка враховує розмір ВВП країни та кількість заявок, поданих резидентами країни. Домовленості про розподіл будуть регулярно переглядатися. Формула розподілу підлягатиме перегляду кожні п’ять років.

Сертифікати додаткового захисту (SPC) - це право інтелектуальної власності, яке служить продовженням патентного права. Вони поширюються на конкретні фармацевтичні засоби та засоби захисту рослин, які були дозволені контролюючими органами. ЄС хоче забезпечити достатній захист цих продуктів в інтересах охорони здоров'я та заохотити інновації в цих сферах. Сертифікати додаткового захисту мають на меті компенсувати втрату патентного захисту на фармацевтичні засоби та засоби захисту рослин, яка виникає внаслідок обов'язкових тривалих випробувань та клінічних випробувань, необхідних цим продуктам до отримання дозволу регуляторного маркетингу.

Авторське право описує виключні права, які регулюють використання певної форми виразу ідеї чи інформації. Історично це право буквально застосовувалося до книгодрукування. На сьогодні авторське право охоплює такі об'єкти, як усі форми літературної творчості, картини, малюнки, скульптури, фотографії, аудіовізуальні твори, програмне забезпечення, радіо- та телепередачі. Авторське право призначене для охорони форми вираження ідей, а не самих ідей [7].

Авторське право гарантує, що автори, композитори, художники, режисери та інші творці отримують охорону результатів своєї творчої діяльності та винагороду за їх використання. Цифрові технології глибоко змінили спосіб виробництва, розповсюдження та доступу до творчого вмісту. Законодавство СС про авторське право - це сукупність директив, які гармонізують основні права авторів та виконавців, продюсерів та телерадіокомпаній. Встановлені стандарти ЄС зменшують національні розбіжності, забезпечують високий рівень охорони, необхідний для сприяння творчій діяльності та інвестиціям у творчість, сприяють культурному різноманіттю. 
Важливий крок на шляху до більшої гармонізації досягнуто у 1993 р. $з$ прийняттям Директиви Ради 93/98/EЕС щодо гармонізації строків охорони авторських прав і деяких суміжних прав. Ця директива встановила загальні строки охорони майнових авторських прав - протягом життя автора та 70 років після його смерті. Нова Директива (2006/116/ЕС), що відмінила Директиву 1993 року, залишила у силі цю норму.

Сьогодні зростає значення нових технологій, таких як блокчейн, 3D-друк та інтернет торгівля, а також розробка нових бізнес-моделей, що стає передумовою модернізації захисту прав інтелектуальної власності.

За останні десятиліття ЄС досягнув значного прогресу в формуванні єдиного ринку інтелектуальної власності. Проте все ще існує багато прогалин та недоліків у цій сфері. По-перше, незважаючи на значний прогрес, частина системи інтелектуальної власності ЄС залишається надто фрагментованою, із складними та дорогими процедурами, які іноді не мають чіткості. Свропейські патенти підлягають дорогим національним процедурам валідації та паралельним судовим розглядам в кількох країнах ЄС. Для фармацевтичних препаратів захист здійснюється за допомогою додаткових сертифікатів захисту (SPC), які доступні лише на національному рівні. Необхідно використовувати потенціал, який пропонують нові технології, такі як штучний інтелект та блокчейн для підвищення ефективності системи охорони інтелектуальної власності ЄС.

По-друге, багато компаній, зокрема малих і середніх, не використовують у повній мірі можливості, які забезпечує система охорони інтелектуальної власності. Лише $9 \%$ малих та середніх підприємств ЄС мають зареєстровані права інтелектуальної власності. Їх небажання користуватися правами інтелектуальної власності багато в чому пояснюється недостатнім знанням про це. Показовим у цьому контексті є кейс у сфері штучного інтелекту: $26 \%$ високоякісних наукових публікацій про штучний інтелект походить з Європи і лише 4 із 30 заявників у цій сфері (13\%) та $7 \%$ підприємств, які займаються патентуванням штучного інтелекту у всьому світі, $\epsilon$ європейськими.

По-третє, інструменти для полегшення доступу до інтелектуальної власності недостатньо розвинені. Криза COVID-19 проілюструвала залежність від критичних інновацій та технологій, особливо у сфері охорони здоров'я.

По-четверте, незважаючи на постійні зусилля, спрямовані на боротьбу 3 підробкою та піратством, ці явища все ще процвітають, у тому числі за рахунок використання цифрових технологій. Імпорт підроблених та піратських товарів до СС становить 121 млрд євро, що становило 6,8 \% імпорту СС у 2016 році (проти 5 \% у 2013 році). Щорічно це призводить до втрати продажів на 50 млрд євро та прямої втрати зайнятості 416000 робочих місць. Кіберкрадіжки комерційних таємниць у ЄС завдають компаніям збитків на суму близько 60 млрд євро щорічно [2].

По-п'яте, на світовому рівні бракує чесної гри, і підприємства ЄС часто програють при діяльності за межами Союзу. Деякі країни, що не входять до $\epsilon C$, недостатньо захищають інтелектуальну власність, що часто завдає шкоди компаніям ЄС.

ЄС повинен використати свій потенціал, щоб виступати в ролі глобального регулятора та активізувати зусилля для боротьби зі зловживаннями у сфері інтелектуальної власності. Система захисту прав інтелектуальної власності є ключовим важелем для підтримки стабільності ЄС та відновлення економіки в період кризи. Щоб взяти на себе лідерство у ключових галузях промисловості, підвищити стабільність у період світової пандемії COVID-19, одночасно переходячи до більш екологічної та цифрової економіки, СС повинен забезпечити збалансовану систему захисту прав інтелектуальної власності, що відповідає сучасним суспільним викликам [8].

У листопаді 2020 р. Комісія прийняла План дій щодо інтелектуальної власності на підтримку відновлення та стабільності ЄС. Він містить пропозиції щодо конкретних заходів у п'яти ключових сферах. Вони спрямовані на удосконалення способів захисту прав інтелектуальної власності, посилення використання IB (передусім у бізнесі), сприяння ліцензуванню та спільному користуванню IB, забезпечення кращої протидії порушенням прав інтелектуальної власності та сприяння чесній грі на глобальному рівні (табл. 1). 
Напрями реформ у сфері інтелектуальної власності ЄС*

\begin{tabular}{|c|c|}
\hline $\begin{array}{l}\text { № } \\
3 / \text { II }\end{array}$ & Сфери та напрями трансформацій \\
\hline \multirow[t]{7}{*}{1} & Поліпшення способів захисту прав інтелектуальної власності \\
\hline & $\checkmark$ підтримка швидкого розгортання унітарної патентної системи \\
\hline & $\checkmark$ оптимізація додаткових сертифікатів захисту \\
\hline & $\checkmark$ модернізація системи захисту конструкції \\
\hline & $\checkmark$ посилення захисту географічних зазначень \\
\hline & $\checkmark$ вдосконалення системи захисту сортів рослин \\
\hline & $\checkmark$ сприяння використанню нових технологій (таких як блокчейн та штучний інтелект) \\
\hline 2 & Посилення використання IB, особливо малим та середнім бізнесом \\
\hline \multirow[t]{5}{*}{3} & Сприяння лічензуванню та спільному користуванню IB \\
\hline & $\checkmark$ забезпечення доступності критичних інновацій у кризові періоди \\
\hline & $\checkmark$ підтримка розвитку високоякісної «інфраструктури авторських прав” \\
\hline & $\checkmark \quad$ покращення прозорості та передбачуваності при ліцензуванні основних патентів \\
\hline & $\checkmark$ сприяння доступу та обміну даними \\
\hline \multirow[t]{4}{*}{4} & $\begin{array}{l}\text { Забезпечення кращих контролю та протидї порущенням прав інтелектуальної } \\
\text { власності }\end{array}$ \\
\hline & $\checkmark$ роз'яснення відповідальності онлайн-платформ у Законі про цифрові послуги \\
\hline & $\checkmark$ запуск інструментарію ЄС проти підробок \\
\hline & $\begin{array}{l}\checkmark \\
\checkmark \text { посилення ролі Європейського бюро протидії шахрайству (OLAF) та інших органів } \\
\text { влади у боротьбі з підробкою та піратством }\end{array}$ \\
\hline \multirow[t]{4}{*}{5} & Сприяти чесній грі на глобальному рівні \\
\hline & $\checkmark$ розробка глобальних стандартів інтелектуальної власності \\
\hline & $\checkmark$ приборкання несправедливої практики \\
\hline & $\checkmark$ розмовляючи єдиним голосом у сфері інтелектуальної власності \\
\hline
\end{tabular}

Висновки і перспективи подальших досліджень. Система охорони прав інтелектуальної власності у $€ \mathrm{C}$ зазнає постійних удосконалень і доповнень. Певні проблемні аспекти закономірно виникають у процесі еволюції єдиної політики СС у сфері охорони прав інтелектуальної власності. Не дивлячись на це, вона є однією з найбільш дієвих і ефективних у світі, гармонійно поєднується 3 процесами розвитку єдиного ринку, підвищення динамізму та конкурентоздатності економіки ЄС, формування інформаційного суспільства 3 високим ступенем інноваційної та інвестиційної привабливості.

Метаморфоза інституційно-правового регулювання інтелектуальної власності $€ C$ має перетворити Союз на центр досконалості у сфері інтелектуальної власності, що надає високоякісні послуги, які допоможуть 3 однієї сторони європейським підприємствам стати більш конкурентоспроможними у світі, а з іншої - Свропа повинна запропонувати користувачам найкраще середовище захисту прав інтелектуальної власності.

У контексті інтересів України співпраця з країнами-членами СС в сфері інтелектуальної власності є невід’ємною складовою курсу на європейську інтеграцію нашої держави.

\section{Джерела та література}

1. Бояр А. О. Єдина політика ЄС у сфері інтелектуальної власності: передумови, формування системи, проблеми і перспективи. Науковий вісник Волинського державного університету імені Лесі Украйнки. Економічні науки. 2006. № 1. С. 277-284.

2. Communication from the Commission to the European Parliament, the Council, the European Economic and Social Committee and the Committee of Regions «Making the most of the EU's innovative potential An intellectual 
property action plan to support the EU's recovery and resilience". Brussels, 25.11.2020 COM(2020) 760 final. URL: https://eur-lex.europa.eu/legal-content/EN/ALL/?uri=CELEX:52020DC0760

3. Directive (EU) No. 2015/2436 of the European Parliament and of the Council of 16 December 2015 to approximate the laws of the Member States relating to trade marks. Official Journal L 336, 23.12.2015, P. 1-26.

4. European Observatory / European Union Intellectual Property Office. URL: https://euipo.europa.eu/ohimportal/en/web/observatory/about-us

5. European Patent Organization (EPO). URL: https://www.epo.org/about-us/at-a-glance.html

6. Governance / EPO. URL: https://www.epo.org/about-us/governance.html

7. Harhoff D. Intellectual Property Rights in Europe - Where do We Stand and Where Should We Go? Prime Minister's Office. Economic Council of Finland. 2006. https://www.researchgate.net/publication/240696278_Intellectual_Property_Rights_in_Europe__Where_do_We_Stand_and_Where_Should_We_Go

8. Intellectual property: Protecting Europe's know-how and innovation leadership / European Commission. URL: https://ec.europa.eu/commission/presscorner/detail/en/IP_17_4942

9. IP Network. Strategic driver / European Union Intellectual Property Office. URL: https://euipo.europa.eu/ohimportal/strategic-drivers/ipnetwork/european-cooperation

10. IP protection in the European Union / Australian government. URL: https://www.ipaustralia.gov.au/understanding-ip/taking-your-ip-global/ip-protection-european-union

11. Protecting intellectual property rights in the EU / European Court of Auditors. URL: https://www.eca.europa.eu/lists/ecadocuments/ap20_13/ap_intellectual_property_rights_en.pdf

12. Strategic Plan 2023 / EPO. URL: https://www.epo.org/about-us/office/strategy.html

13. The Office / European Union Intellectual Property Office. URL: https://euipo.europa.eu/ohimportal/en/theoffice

14. Unitary patent: 26 countries agree on distribution key / European Commission. URL: https://ec.europa.eu/growth/content/unitary-patent-26-countries-agree-distribution-key_en

\section{References}

1.Boiar A. O. (2006) Yedyna polityka EU u sferi intelektualnoi vlasnosti: peredumovy, formuvannia systemy, problemy i perspektyvy. Naukovyi visnyk Volynskoho derzhavnoho universytetu imeni Lesi Ukrainky. Ekonomichni nauky - Scientific Journal of Lesya Ukrainka Volyn State University. Economic Sciences. № 1. S. 277-284 [in Ukrainian].

2. Communication from the Commission to the European Parliament, the Council, the European Economic and Social Committee and the Committee of Regions «Making the most of the EU's innovative potential An intellectual property action plan to support the EU's recovery and resilience". Brussels, 25.11.2020 COM(2020) 760 final. URL: https://eur-lex.europa.eu/legal-content/EN/ALL/?uri=CELEX:52020DC0760

3. Directive (EU) No. 2015/2436 of the European Parliament and of the Council of 16 December 2015 to approximate the laws of the Member States relating to trade marks. Official Journal L 336, 23.12.2015, P. 1-26.

4. European Observatory / European Union Intellectual Property Office. URL: https://euipo.europa.eu/ohimportal/en/web/observatory/about-us

5. European Patent Organization (EPO). URL: https://www.epo.org/about-us/at-a-glance.html

6. Governance / EPO. URL: https://www.epo.org/about-us/governance.html

7. Harhoff D. (2006) Intellectual Property Rights in Europe - Where do We Stand and Where Should We Go? Prime Minister's Office. Economic Council of Finland. https://www.researchgate.net/publication/240696278_Intellectual_Property_Rights_in_Europe_Where do_We_Stand and Where_Should_We_Go

8. Intellectual property: Protecting Europe's know-how and innovation leadership / European Commission. URL: https://ec.europa.eu/commission/presscorner/detail/en/IP_17_4942

9. IP Network. Strategic driver / European Union Intellectual Property Office. URL: https://euipo.europa.eu/ohimportal/strategic-drivers/ipnetwork/european-cooperation

10. IP protection in the European Union / Australian government. URL: https://www.ipaustralia.gov.au/understanding-ip/taking-your-ip-global/ip-protection-european-union

11. Protecting intellectual property rights in the EU / European Court of Auditors. URL: https://www.eca.europa.eu/lists/ecadocuments/ap20_13/ap_intellectual_property_rights_en.pdf

12.Strategic Plan 2023 / EPO. URL: https://www.epo.org/about-us/office/strategy.html

13. The Office / European Union Intellectual Property Office. URL: https://euipo.europa.eu/ohimportal/en/theoffice

14. Unitary patent: 26 countries agree on distribution key / European Commission. URL: https://ec.europa.eu/growth/content/unitary-patent-26-countries-agree-distribution-key_en 